\title{
Family Decision Making on Cultural Heritage
}

\author{
Gita Widya Laksmini Soerjoatmodjo, Veronica Anastasia Melany Kaihatu \\ Department of Psychology, \\ Pembangunan Jaya University, Indonesia \\ gita.soerjoatmodjo@upj.ac.id
}

\begin{abstract}
AkhirPekan@MuseumNasional or Weekend at Museum Nasional is a Sunday family 15-20-minute theatre program organized by a museum consultancy, @Museum, in collaboration with Teater Koma for Indonesia's National Museum. As a follow-up research, it zooms in on the decision-making process which leads to family participation in this cultural heritage appreciation program. Semistructured interviews in this preliminary qualitative research to families attending the program show that aspiration, prior experience and the roles of mothers contributes to the process. It is hoped that this writing would provide feedbacks to other similar initiatives which promote the appreciation of cultural heritage.

Keywords: heritage appreciation; consumer behaviour; family decision-making process; museum learning

eISSN: 2398-4279 @ 2017. The Authors. Published for AMER ABRA by e-International Publishing House, Ltd., UK. This is an open access article under the CC BY-NC-ND license (http://creativecommons.org/licenses/by-ncnd/4.0/). Peer-review under responsibility of AMER (Association of Malaysian Environment-Behaviour Researchers), ABRA (Association of Behavioural Researchers on Asians) and cE-Bs (Centre for EnvironmentBehaviour Studies), Faculty of Architecture, Planning \& Surveying, UniversitiTeknologi MARA, Malaysia. https://doi.org/10.21834/ajqol.v2i5.7
\end{abstract}




\subsection{Introduction}

The quality of life is a multi-faceted concept which encompasses cultural aspect. Hence, cultural heritage preservation plays key roles in the quality of life.

The following is an example of a cultural heritage appreciation program. AkhirPekan@MuseumNasional or Weekend at Museum Nasional is a Sunday 15-to-20minute theatre for family organized by a museum consultancy, @Museum, in collaboration with the renowned Teater Koma for Indonesia's National Museum. Despite its prime location in the heart of Jakarta and highly affordable ticket prices (Rp 7,000 or 0.54 USD for adult and Rp 5,000 or 0.39 USD for children), this 237 -year-old museum has a meagre 208,000 visitors in 2011 - insignificant compared to 847,000 visitors per year for National Museum of Singapore or 10 million visitors per year for Louvre Museum in France (Mariana, 2013).

Inspired by more than 140,000 museum artefacts, this free-of-charge program is performed at the gallery where the related collection is on display. These performances of Keris Puputan Klungkung (The Klungkung Daggers) (Teater Koma, 2013, 11 September), Samurai Bersepeda (The Cycling Samurai) (Teater Koma, 2013, 26 September), Karamnya Kapal Tek Sing (The Drowning of the Tek Sing Jung) (Teater Koma, 2013, 11 October), Raibnya Celengan Majapahit (The Disappearance of the Majapahit Piggy Bank) (Teater Koma, 2014a, 4 November), Kuda Perang Pangeran Diponegoro (Prince Diponegoro's War Horse) (Teater Koma, 2014a, 24 January) and Raksasa Bhairawa Pengasah Parang (Bhairawa, the Blade Wielding Giant) (Teater Koma, 2014b, 24 January), are showcased September to December 2013 and promoted via social media. It highlights how storytelling cultivates public engagement to appreciate cultural heritage (Soerjoatmodjo (2014).

The program continues May-October 2014, encompassing Raksasa Bhairawa Pengasah Parang (Bhairawa, the Blade Wielding Giant) (Teater Koma, 2014b, 24 January), Monalisa dari Singhasari (Monalisa from Singhasari) (Teater Koma, 2014a, 4 November), Semerbak Penggoda Raja Kelana Pelaut (The Fragrance that Launched a Thousand Ships) (Teater Koma, 2014b, 4 November), Wayang Kalijaga, si Brandal Lokajaya (Kalijaga's Shadow Puppet, The Thug from Lokajaya) (Teater Koma, 2014c, 4 November), Ribut-Ribut si Bumbung dan si Coak (Bumbung and Coak's Salvo Serenade) (Teater Koma, 2014d, 4 November), Nenek Moyangku Orang Pelaut (Sailors are My Ancestors) (Teater Koma, 2014e, 4 November) and Habis Gelap Terbitlah Terang (Through the Darkness Into the Light).

This writing is a follow up from Soerjoatmodjo (2014) on AkhirPekan@MuseumNasional in September-December 2013. As it focuses on the same program on May-October 2014 period, it investigates further. The objective is: how families undertake their decision-making process to appreciate cultural heritage through AkhirPekan@MuseumNasional program? 


\subsection{Literature Review}

Previous research showcases how storytelling can create public engagement with cultural heritage (Soerjoatmodjo, 2014). Creative approaches can be used in museum learning by developing a sense of belonging (Simşek \& Kesici, 2012). Cultural heritage appreciation contributes to children's intellectual, physical, emotional, cognitive, social and aesthetical developments (Günay (2012) and Shamsidar, Abbas, Yusof \& Taib (2013).

Museums target families as main consumers (Haas, 2007). Museum learning shapes children's understanding about museum collection and the overall learning experience (Shamsidar, Abbas, Yusof \& Taib, 2014). Despite the benefits, parents prefer spending time with their children in other leisure activities rather than in cultural variants (Lupu, Laurentiu \& Norel 2013). Research on museum programs focuses only on the family duration of stay and spending behaviour in the museum (Teo, Khan \& Rahim, 2013). Further studies are needed to examine how families get involved in cultural heritage appreciation in museums (Aslan \& Aslan, 2012). A better understanding would hopefully contribute to museums in Indonesia - a total of 262 (Munandar et al., 2011).

Family comprises of at least two individuals - a householder and another related individual by blood, marriage or adoption ties (Peter \& Olson, 2010). Family comprises of members from generations with different needs and wants interacting and influencing each other. Families are consumers making decision in choosing goods and service - including leisure activities including heritage programs (Tanksale, Neelam \& Venkatachalam, 2013). Families play key roles in financial transaction to purchase, subscribe or obtain cultural contents including experience (Rizzo \& Mignosa, 2013).

The decision is defined as a goal-directed, problem-solving motivated act of choosing amongst two or more alternatives (Peter \& Olson, 2010). Family goes through decisionmaking process cycle (Kolb, 2013):

1. Problem or need recognition

2. Information search

3. Evaluation of alternatives

4. Decision-making

5. Post decision-making evaluation

Family members play different roles in decision-making process regarding leisure activities (Peter \& Olson, 2010):

1. Influencer - providing information to the family.

2. Gatekeeper - controlling information to the family.

3. Decider - deciding product or service for the family.

4. Buyer - purchasing product or service for the family.

5. User - using product or service for the family.

6. Disposer -terminating family use of product or service. 
In this process, mothers are known to play dominant roles (Mottiar \& Quinn, 2003). Mothers are the ones who start the discussion, gather information up to take action in technical aspects (Solomon, 2013). The understanding decision-making process of families participating in AkhirPekan@MuseumNasional would contribute to the quality of life advancement.

\subsection{Methodology}

The objective of the research requires qualitative method because it suits with the exploration of new products and services at various stage of development (Keegan, 2009). This writing adopts case study as the strategy of inquiry on AkhirPekan@MuseumNasional. A case study is a useful design to have a holistic view as it provides an overview and indepth understanding of a case, process and interactional dynamics within a unit of study (Kumar, 2011). Limitations are that findings cannot be generalized to a general population, yet it can be transferable to another similar setting in some degree (Merriams, 2009).

This writing uses the semi-structured interview to allow subject comparisons while opening doors to flexibility (Steward \& Cash, 2006). Authors greet the attending families with children of 6-12 years old who are key beneficiaries of museum learning. Authors explain the research purpose, provide informed consent forms to be signed and then conduct face-to-face 30- to 60-minute interviews done with parents while children are welcome to add their point of views if they have any. Approached used is interpretative phenomenology analysis as it allows idiographic focus to explore how a given person, in a given context, makes sense of a given phenomenon and enables a close examination of the experiences and meaning-making activities (Smith, Flowers \& Larkins, 2009). A reasonably homogenous pool of participants is useful in interpretative phenomenological analysis because the purpose is to capture the essential sense making of the participating subjects in details (Smith \& Osborn, 2008) Audio recordings are transcribed in verbatim to be analysed into coding, according to stages as proposed by Storey (2007) in Pearce, Filep \& Ross (2011): (1) initial readings to find coherent meaning and themes, (2) theme identification and labelling, (3) establishing theme linkages and (4) producing a summary table of themes with illustrative quotations; with constant reflection and re-examination throughout the process.

\subsection{Results and Discussions}

In May-October 2014, there are 21 families interviewed or 1 for each session. Interviews transcribed and analysed help authors to pick selected families based on clarity and elaboration in describing the decision-making process they undertake. This results in 7 families chosen and all parents are 40 years old and above. Findings derived from families interviewed are described in Table 1: 
Table 1. Subjects

\begin{tabular}{|l|l|l|l|l|l|l|l|l|}
\hline \multirow{2}{*}{ Family Descriptions } & \multicolumn{7}{|c|}{ Family } \\
\cline { 3 - 9 } \multicolumn{2}{|c|}{} & 1 & 2 & 3 & 4 & 5 & 6 & 7 \\
\hline $\begin{array}{l}\text { Edu-cation } \\
\text { back- } \\
\text { ground }\end{array}$ & Father & $\begin{array}{l}\text { Under } \\
\text { grad }\end{array}$ & $\begin{array}{l}\text { Post } \\
\text { grad }\end{array}$ & $\begin{array}{l}\text { Under } \\
\text { Grad }\end{array}$ & $\begin{array}{l}\text { Post } \\
\text { Grad }\end{array}$ & $\begin{array}{l}\text { Post } \\
\text { Grad }\end{array}$ & $\begin{array}{l}\text { Under } \\
\text { grad }\end{array}$ & $\begin{array}{l}\text { Under } \\
\text { Grad }\end{array}$ \\
\cline { 2 - 9 } & Mother & $\begin{array}{l}\text { Post } \\
\text { grad }\end{array}$ & $\begin{array}{l}\text { Post } \\
\text { Grad }\end{array}$ & $\begin{array}{l}\text { Under } \\
\text { Grad }\end{array}$ & $\begin{array}{l}\text { Under } \\
\text { Grad }\end{array}$ & $\begin{array}{l}\text { Post } \\
\text { Grad }\end{array}$ & Post grad & $\begin{array}{l}\text { Under } \\
\text { Grad }\end{array}$ \\
\hline $\begin{array}{l}\text { Profes- } \\
\text { sional } \\
\text { back- } \\
\text { ground }\end{array}$ & Father & $\begin{array}{l}\text { Private } \\
\text { sector }\end{array}$ & $\begin{array}{l}\text { Private } \\
\text { sector }\end{array}$ & $\begin{array}{l}\text { Intl } \\
\text { NGO }\end{array}$ & $\begin{array}{l}\text { Private } \\
\text { sector }\end{array}$ & $\begin{array}{l}\text { Entre- } \\
\text { preneu } \\
\text { r }\end{array}$ & $\begin{array}{l}\text { Public } \\
\text { ser-vant }\end{array}$ & $\begin{array}{l}\text { Private } \\
\text { sector }\end{array}$ \\
\cline { 2 - 9 } & Mother & $\begin{array}{l}\text { Private } \\
\text { sector }\end{array}$ & $\begin{array}{l}\text { Private } \\
\text { sector }\end{array}$ & $\begin{array}{l}\text { Not } \\
\text { em- } \\
\text { ployed }\end{array}$ & $\begin{array}{l}\text { Public } \\
\text { servan } \\
\text { t }\end{array}$ & $\begin{array}{l}\text { Private } \\
\text { sector }\end{array}$ & $\begin{array}{l}\text { Pri-vate } \\
\text { sector }\end{array}$ & $\begin{array}{l}\text { Entre- } \\
\text { preneur }\end{array}$ \\
\hline Family Size & 3 & 4 & 4 & 3 & 4 & 4 & 3 \\
\hline Source of information & $\begin{array}{l}\text { Social } \\
\text { media }\end{array}$ & $\begin{array}{l}\text { Social } \\
\text { media }\end{array}$ & $\begin{array}{l}\text { Social } \\
\text { media }\end{array}$ & $\begin{array}{l}\text { Social } \\
\text { media }\end{array}$ & $\begin{array}{l}\text { Social } \\
\text { media }\end{array}$ & $\begin{array}{l}\text { Social } \\
\text { media }\end{array}$ & $\begin{array}{l}\text { Social } \\
\text { media }\end{array}$ \\
\hline
\end{tabular}

Findings show stages of the family decision-making process. Families express aspiration as part of their decisions to choose cultural heritage appreciation. In family aspiration stages parents express their wish for their children to appreciate culture heritage. Next is the family prior experience. Parents are exposed to experiences such as watching theatres or taking part in museum programs. Hence, parents would like to expose children to similar opportunities. Reflection of family aspiration and family prior experience imply the relationship with family background, be it educational, professional and social. Aspiration and prior experience contribute to taking part in the program.

Families move forward to need recognition, in which families recognize the need to spend leisure time in the weekend. Next, parents conduct information search via social media networks on technical aspects of the performance such as duration and content of the performance and the artefacts' historical background. Families proceed to the next stage of evaluating alternatives of locations and schedules. Decision-making is done by making reservations via phone calls or emails. The last stage is post-decision-making evaluation, as families reflect on their decision by discussing the experience to assess whether it matches their expectation. The overall stages of family decision-making process in participating in cultural heritage appreciation are captured in Figure 1.

This finding captures that in the context of cultural heritage appreciation, family aspiration and prior experience are two additional stages. Subjects' reflections on the family decisionmaking experience uncover aspiration and prior experience of family interviewed for this research, encapsulated in the Table 2:

Findings also show that fathers and mothers participate differently. The table shows how mothers are key decision makers in stages such as information search, evaluation of alternatives as well as decision-making while fathers play supporting roles. Key concerns of mothers in going are the benefits of the program to the children, specifically educational and 
socio-cultural values. This pattern emerges even though fathers and mothers sampled in the research have varied educational and professional backgrounds. This is captured in the following Table 3.

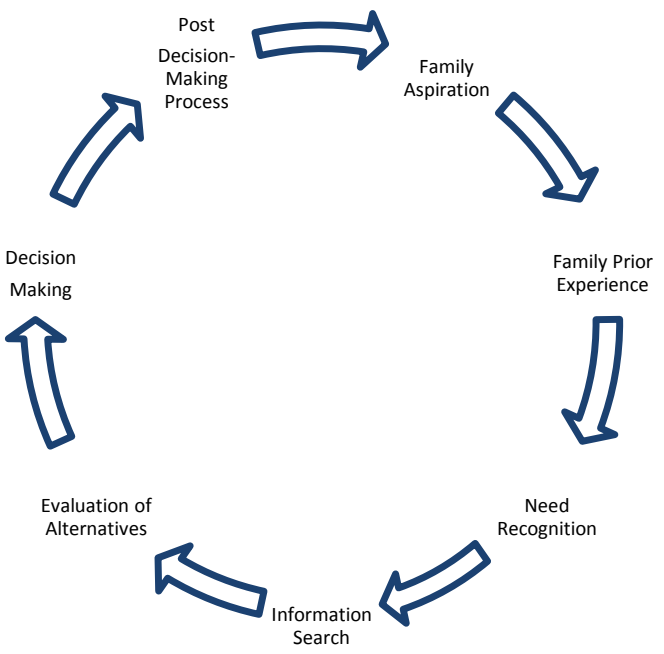

Figure 1. Stages of Family Decision-Making Process

Table 2. Family Aspiration and Family Prior Experience

\begin{tabular}{|l|l|}
\hline \multicolumn{1}{|c|}{ Family Aspiration } & \multicolumn{1}{|c|}{ Family Prior Experience } \\
\hline $\begin{array}{l}\text { Children to be aware of their } \\
\text { cultural identity, to understand their historical roots, } \\
\text { to build strong national pride as Indonesians, to } \\
\text { develop cultural appreciation }\end{array}$ & $\begin{array}{l}\text { Theatre, music, dance, } \\
\text { other contemporary art } \\
\text { forms, museum/gallery visits. }\end{array}$ \\
\hline
\end{tabular}

Table 3. Dominant Decision Makers

\begin{tabular}{lcc}
\hline Stages & \multicolumn{2}{c}{ Dominant Decision-Makers } \\
\cline { 2 - 3 } & Father & Mother \\
\hline Family Aspiration & $\mathrm{X}$ & $\mathrm{X}$ \\
\hline Family Prior Experience & $\mathrm{X}$ & $\mathrm{X}$ \\
\hline Need Recognition & $\mathrm{X}$ & $\mathrm{X}$ \\
\hline Information Search & & $\mathrm{X}$ \\
\hline Evaluation of Alternatives & $\mathrm{X}$ \\
\hline Decision-Making & $\mathrm{X}$ & $\mathrm{X}$ \\
\hline Post-Decision-Making Evaluation & $\mathrm{X}$ & $\mathrm{X}$ \\
\hline
\end{tabular}


Further analysis of the roles of mothers shows that as consumers, they take the roles as influencer, gatekeepers, deciders as well as buyers for the family. In terms of users and disposers, based on the information provided in the interview, the family would come to a consensus on those issues - also facilitated by mothers. Roles of mothers are captured in Figure 2.

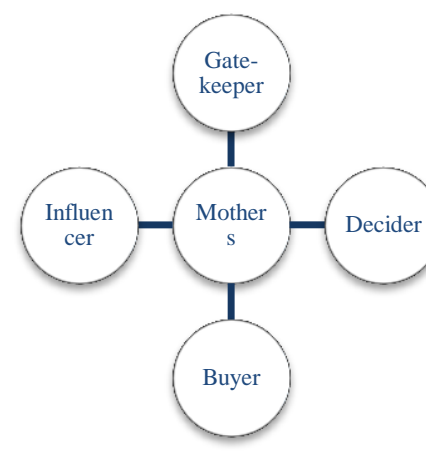

Figure 2. Roles of Mothers

Findings show mothers play key roles in all stages while fathers take more supporting roles. Children are being consulted, bearing in mind that educational and socio-cultural benefits serve as anchors of the overall process.

\subsection{Conclusion}

This current research contributes to better understanding of family decision-making process to a cultural heritage appreciation program offered by the National Museum. Findings lead to the identification of additional stages - family aspiration and family prior experience, in which both fathers and mothers are involved. Since mothers show a more prominent role in the family decision-making process, this opens up avenues for museums or their consulting agencies to engage families as consumers. Museums can design programs specifically targeted to appeal to mothers. Further research can also take the avenue of quantitative research by adopting numbers to measure it further - e.g. which artefacts appeal the most to a specific group of audience, level of engagement of museum visitors, changed perspective toward the roles of the museum and so forth.

\section{Acknowledgement}

This research is made possible by Hibah Penelitian Fundamental research grant from Pusat Penelitian dan Pengabdian Masyarakat, Universitas Pembangunan Jaya, Tangerang 
Selatan, Indonesia. For the sake of transparency, it should be mentioned that the author of this writing is married to the @Museum producer. The objectivity of the writing is attempted as follow. As @Museum team provides access, the author works independently in data gathering as well as data analysis process throughout the implementation of AkhirPekan@MuseumNasional program. Meanwhile, the level of attention to its idiosyncratic complexity of the data is ensured from the author's role as the researcher in the previous research regarding the same program. The author also discusses the process and shares the writing to colleagues of Department of Psychology Pembangunan Jaya University for peer reviews and the author is grateful for their inputs.

\section{References}

Aslan, N. \& Aslan, K. (2012) What is leisure for Turkish parents? Procedia Social and Behavioral Sciences 55 (2012) 390-39 doi:10.1016/j.sbspro.2012.09.517

Günay, B. (2012) Museum concept from past to present and importance of museums as centers of art education Procedia Social and Behavior Sciences 55 (2012) 12501258 doi:10.1016/j.sbspro.2012.09.622

Haas, C. (2007) Families and children challenging the museumin Lord B. (editor) The manual of museum learning Lanham: AltaMira Press

Keegan, S. (2009) Qualitative research: good decision-making through understanding people, cultures and making London: Kogan Page

Kolb, B. M. (2013) Marketing for cultural organizations: new strategies for attracting and engaging audiences $3^{\text {rd }}$ edition New York: Taylor \& Francis.

Kumar, R. (2011) Research methodology: a step-by- step guide for beginners London: Sage.

Lupu, D., Laurentiu, A.R. \& Norel, M. (2013) Parents ask: what should we do with preschool children in their spare time? Procedia - Social and Behavioral Sciences 127 (2014) 21-25 doi: 10.1016/j.sbspro.2014.03.205

Mariani, E. (2013) Telling tales at the National Museum published in The Jakarta Post October 11, 2013, and accessed from http://www.thejakartapost.com/news/2013/10/11/telling-tales-national-museum.html on February 20, 2014.

Merriam, S.B. (2009) Qualitative research: a guide to design and implementation $2^{\text {nd }}$ edition San Francisco: John Wiley \& Sons.

Munandar, A.A. et al (2011) Sejarah Permuseuman di Indonesia Jakarta: Direktorat Permuseuman.

Mottiar, Z. \& Quinn, D. (2003) Couple dynamic in household tourism decision making: women as the gatekeepers? Journal of vacation marketing April 2004 Vol. 10 No. 2 pp. 149-160.

Peter J.P. \& Olson, J.C. (2010) Consumer Behavior and Marketing Strategy $9^{\text {th }}$ edition New York: McGraw-Hill International Edition. 
Pearce, P., Filep, S. \& Ross, G. (2011) Tourists, tourism and the good life. New York: Routledge.

Ruso, L. \& Topdal, E.B. (2014) The use of museums for educational purposes using drama method Procedia Social and Behavioral Science 141 (2014) 628-632 doi: 10.1016/j.sbspro.2014.05.110

Shamsidar, A., Abbas, M.Y., Yusof, W.Z.M. \& Taib, M. Z.M. (2013) Museum learning: using research as best practice in creating future museum exhibition Procedia Social and Behavioral Sciences 105 (2013) 370-382. doi: 10.1016/j.sbspro.2013.11.039

Shamsidar, A., Abbas, M.Y., Yusof, W.Z.M. \& Taib, M. Z.M. (2014) Adapting museum visitor as participants benefits their learning experience? Procedia Social and Behavioral Sciences 168 (2015) 156-170. doi: 10.1016/j.sbspro.2014.10.221

Simşek, G. \& Kesici, E. (2012) Heritage education for primary school children through drama: the case of Aydin, Turkey Procedia Social and Behavioral Sciences 46 (2016) 3817-3824 doi: 10.1016/j.sbspro.2012.06.153

Solomon, M.R. (2013) Consumer Behavior: Buying, Having and Being $9^{\text {th }}$ edition New York: Pearson Prentice Hall.

Soerjoatmodjo, G.W.L. (2014) Storytelling, cultural heritage and public engagement in AkhirPekan@MuseumNasional Procedia Social and Behavioural Science 184 (2015) 87-94. doi: 10.1016/j.sbspro.2015.05.057

Smith, J.A., Flowers, P. \& Larkin, M. (2009) Interpretative phenomenology analysis: theory, method and research. London: Sage Publications.

Smith, J.A. \& Osborn, M. (2008) Interpretative phenomenology analysis in Smith, J.A. (Ed) Qualitative Psychology: A Practical Guide to Research Methods London: Sage Publication.

Steward, C.J. \& Cash, W.B. (2006) Interviewing: principles and practices $11^{\text {th }}$ edition New York: McGraw-Hill International Edition

Tanksale, D., Neelam, N. \& Venkatachalam, R. (2014) Consumer decision-making styles of young adult consumers in India Procedia Social and Behavioral Sciences 133 (2014) 211-218 doi: 10.1016/j.sbspro.2014.04.186

Teo, C.B.C., Khan, N.R.M. \& Rahim, F.H.A. (2013) Understanding cultural heritage visitor behavior: the case of Melaka as world heritage city Procedia Social and Behavioral Sciences 130 (2014) 1-10 doi: 10.1016/j.sbspro.2014.04.001

Teater Koma (2013, 11 September) AkhirPekan@MuseumNasional - Keris Puputan Klungkung [Video file] Retrieved from http://www.youtube.com/watch?v=_ZSCi4dYRql

Teater Koma (2013, 26 September) AkhirPekan@MuseumNasional - Samurai Bersepeda [Video file] Retrieved from http://www.youtube.com/watch?v=Ve6aq1EXrws

Teater Koma (2013, 11 October) AkhirPekan@MuseumNasional - Tenggelamnya Kapal Tek Sing [Video file] Retrieved from http://www.youtube.com/watch?v=DwnpjQVmeck

Teater Koma (2014a, 24 January) AkhirPekan@MuseumNasional - Raksasa Bhairawa Pengasah Parang [Video file] Retrieved from https://www.youtube.com/watch?v=D5L2yd_mQ8s

Teater Koma (2014b, 24 January) AkhirPekan@MuseumNasional - Raibnya Celengan Majapahit [Video file] Retrieved from http://www.youtube.com/embed/h-Mz98IT168 
Teater Koma (2014a, 4 November) AkhirPekan@MuseumNasional - Monalisa dari Singhasari [Video file] Retrieved from

https://www.youtube.com/watch?v=B5RA2RnA3BY

Teater Koma (2014b, 4 November) Akhir Pekan@Museum Nasional - Semerbak Penggoda Raja Kelana [Video file] Retrieved from https://www.youtube.com/watch?v=yeRfzsFXhUU

Teater Koma (2014c, 4 November) AkhirPekan@MuseumNasional - Wayang Kalijaga Parang [Video file] Retrieved from https://www.youtube.com/watch?v=2xf0mtChXRE

Teater Koma (2014d, 4 November) AkhirPekan@MuseumNasional - Ribut-Ribut si Bumbung dan si Coak [Video file] Retrieved from https://www.youtube.com/watch?v=cbllGz7Td-E

Teater Koma (2014e, 4 November) AkhirPekan@MuseumNasional - Nenek Moyangku Orang Pelaut [Video file] Retrieved from https://www.youtube.com/watch?v=vy8vatC-tFI\&list=PL2gonoMwL3W1kkvnzjBiS4yrLH81TKfO\&index $=2$ 